\title{
Avenues for Professional Development: Faculty Perspectives from an Indian Medical School Abraham RR, ${ }^{1}$ Pallath $\mathrm{V},{ }^{2}$ AM C, ${ }^{2}$ Ramnarayan $\mathrm{K}^{3}{ }^{3}$ Kamath $\mathrm{A}^{4}$
}

\author{
${ }^{1}$ Department of Physiology \\ ${ }^{2}$ Department of Microbiology \\ ${ }^{3}$ Department of Pathology
}

Melaka Manipal Medical College (Manipal Campus) Manipal University, Manipal,Karnataka, India

${ }^{4}$ Department of Community Medicine

Kasturba Medical College, Manipal University Manipal, Karnataka, India

\section{Corresponding Author}

Reem Rachel Abraham

Department of Physiology

Melaka Manipal Medical College (Manipal Campus) International Centre for Health Sciences

Manipal - 576104

Karnataka state, India

E-mail: reemabraham@gmail.com

Citation

Abraham RR, Pallath V, AM C, Ramnarayan K, Kamath A. Avenues for Professional Development: Faculty Perspectives from an Indian Medical School. Kathmandu Univ med J 2012;10(3):60-65.

\begin{abstract}
Background

Medical school faculty in India are challenged to balance teaching and professional development. Melaka Manipal Medical College (MMMC), Manipal Campus, Manipal University, India offers the Bachelor of Medicine and Bachelor of Surgery (MBBS) program. The institution incorporates certain effective practices based on adult learning principles which are aimed at fostering the professional development of faculty members.
\end{abstract}

\section{Objectives}

The present study was undertaken to explore the perceptions of faculty members regarding the scope for professional development at Melaka Manipal Medical College, Manipal Campus.

\section{Methods}

In September 2009, a questionnaire comprising items (23) focusing on five adult learning principles (active participation, relevant learning, constructive feedback, safe, non-threatening environment and previous experiences) was designed and faculty members $(n=23)$ were asked to respond to it on a 5-point Likert scale. Additionally, a force field analysis was conducted by asking the faculty to identify three factors which facilitated them to consciously get involved in professional development activities. They were also asked to identify three unfavorable factors that hindered their professional development.

Results

Among the five characteristics, relevant learning was found to have a high mean score. Frequency analysis of responses revealed that at Melaka Manipal Medical College, there was ample scope for relevant self-learning that fosters professional development (91.3\%). Force field response analysis revealed Melaka Manipal Medical College offered considerable flexibility and opportunities for continuing professional development along with faculty members' prevailing role as teachers. Nevertheless, the need for more research facilities and funds was highlighted.

\section{Conclusions}

Adherence to adult learning principles may provide avenues for professional development in medical schools. An organized attempt to make the medical school faculty aware of the scope of these practices appears to be necessary to nurture professional development in settings where there are resource constraints.

\section{KEY WORDS}

Adult learning, professional development, self-directed learning 


\section{INTRODUCTION}

In the prevailing medical education scenario in India, medical school faculties are expected to balance teaching and involvement in activities of professional development. They are no longer appreciated only on their skills in teaching, but also on their active participation in other professional acitivities. This is challenging for many medical teachers in India due to lack of proper orientation, poor infrastructure at the work place and inadequate rewards for those who want to grow academically. ${ }^{1,2}$ Nevertheless, the faculty members are forced to get involved in research. Adkoli and Rita in their study on medical school faculty in India has discussed the urgent need of Indian medical school faculty members to move from teacher training to the wider arenas of professional development and research. ${ }^{3}$

As stated by Malcolm Knowles, most adults are intrinsically motivated to involve themselves in learning. ${ }^{4,5}$ But, the importance of extrinsic motivation cannot be underestimated, especially when the facilities for research are minimal. In this context, encouraging a few effective practices based on adult learning principles among faculty is the need for the day in Indian medical schools.

Adult learning encompasses the following characteristics: ${ }^{4-6}$

- Active participation in self-directed learning activities

- Learning based on previous experiences

- Relevant learning based on the extent to which the need is felt

- Learning in safe non-threatening environment

- Learning based on constructive feedback

Melaka Manipal Medical College (MMMC), Manipal Campus, Manipal University, incorporates certain effective practices based on adult learning principles which are aimed at fostering the professional development of faculty members. This paper aims to reflect on perceptions of faculty members at India regarding the scope for professional development at MMMC.

\section{METHOD}

The present study was conducted at Melaka Manipal Medical College (MMMC), Manipal Campus, Manipal University, India and has been approved by the Institutional Research Committee. MMMC offers Bachelor of Medicine and Bachelor of Surgery (MBBS) program in two campuses; one at Manipal, India and the other at Melaka, Malaysia. The program envisages two and a half years of preclinical training at Manipal and another two and a half years at Melaka, Malaysia. Majority of the students are from Malaysia (98 percent) and the rest are from Seychelles, Australia and Singapore.
Initially in September 2009, a focus group discussion was conducted among selected faculty of Melaka Manipal Medical College, comprising of nine faculty members belonging to lecturer, senior grade lecturer, assistant professor, associate professor and professor categories. In the focus group discussion which was about one hour duration, the participants' perceptions regarding adult learning was discussed. Based on the data generated and a literature review, a questionnaire comprising of items focusing on adult learning principles was designed (Table 1). It had five subscales: Active Participation (AP; three items), Relevant Learning (RL; four items), Safe, nonthreatening Environment (SE; ten items), Constructive Feedback (CF; four items), and Previous Experiences (PE; three items). The questionnaire also consisted of questions related to the teaching experience of faculty members and their involvement in professional development activities after joining MMMC. The questionnaire was checked for reliability by measuring the internal consistency.

Following this, the faculty members ( $n=23$ ) were requested to respond to the questionnaire on a five point scale (five=strongly agree; four=Agree; three =Uncertain; two =Disagree; one=strongly disagree). Junior faculty members $(n=12)$ who had not completed minimum one year of service were excluded from the study. Additionally, a force field analysis was conducted by asking the faculty to identify three factors (minimum ) favorable and unfavorable each, which encouraged them to be consciously involve in professional development activities, in addition to their routine work at $\mathrm{MMMC}^{7}$ As data was following normal distribution, data was summarized using mean and standard deviation. Frequency analysis of the responses were also performed an agreement to each item was calculated by adding the frequencies of strongly agree and agree responses. Disagreement to each item was calculated by adding the frequencies of strongly disagree and disagree responses.

\section{RESULTS}

The response rate was 100 percent. Reliability of the questionnaire was found to be high (Chronbach $\alpha=0.82$ ). Among the five characteristics, relevant learning (Fig 1) was found to have a high mean value, followed by safe nonthreatening environment (Fig 2) constructive feedback (Fig 3), active participation (Fig 4) and previous experiences (Fig 5). Analysis of responses revealed a low rating (Mean 1.6 and 1.95 respectively) for items17 (After joining MMMC, I have no scope for further professional development) and 19 ( $\mathrm{l}$ am inhibited in my professional development activities/research because of interference from my peers). Among the items under 'active participation', item eight (I spend time beyond working hours for selfdirected learning activities leading to my professional development) received the highest rating. Item 13 received the highest rating in 'relevant learning' and items 18 (The 
Table 1. Questionnaire along with the frequency analysis of responses.

\begin{tabular}{|c|c|c|c|c|c|c|}
\hline & & & Yes & Items & Cumulative & Cumulative \\
\hline 1 & $\begin{array}{l}\text { *Have you worked in places other tha } \\
\text { If yes, please indicate your experience } \\
\text { months. (If Yes, please answer item } 28 \\
\text { please don't respond to item } 28 \text { ) }\end{array}$ & $\begin{array}{l}\text { MMMC? } \\
\text { in years/ } \\
\text {; If No, }\end{array}$ & & & $\begin{array}{l}\text { of Agree } \\
\text { to strongly } \\
\text { agree (\%) }\end{array}$ & $\begin{array}{l}\text { of Neutral } \\
\text { to strongly } \\
\text { disagree } \\
\text { (\%) }\end{array}$ \\
\hline 2 & $\begin{array}{l}\text { Have you been involved in any researc } \\
\text { studies after you joined MMMC? }\end{array}$ & h projects/ & & $\begin{array}{l}\text { 20. My superiors at MMMC are sup- } \\
\text { portive in my professional development } \\
\text { activities }\end{array}$ & 73.9 & 26.1 \\
\hline 3 & $\begin{array}{l}\text { If Yes, kindly indicate the number of } p \\
\text { studies/papers published/presentatio } \\
\text { ences after you joined MMMC }\end{array}$ & $\begin{array}{l}\text { ojects/ } \\
\text { ts in confer- }\end{array}$ & & $\begin{array}{l}\text { 21. At MMMC, self-directed learning } \\
\text { activities can be carried out at my own } \\
\text { pace }\end{array}$ & 73.9 & 26.1 \\
\hline 4 & $\begin{array}{l}\text { Have you enrolled yourselves in any k } \\
\text { education course/s which earned you } \\
\text { after joining MMMC? }\end{array}$ & $\begin{array}{l}\text { nd of higher } \\
\text { a degree }\end{array}$ & & $\begin{array}{l}\text { 24. I am guided by a faculty member } \\
\text { (mentor) at MMMC, for my professional } \\
\text { development }\end{array}$ & 47.8 & 52.2 \\
\hline 5 & $\begin{array}{l}\text { Have you undertaken any fellowship } p \\
\text { aimed at professional development af } \\
\text { joined MMMC? }\end{array}$ & $\begin{array}{l}\text { rograms } \\
\text { ter you }\end{array}$ & & $\begin{array}{l}\text { 30. I have role models at MMMC for my } \\
\text { professional development }\end{array}$ & 91.3 & 8.7 \\
\hline 6 & Have you been involved in work/s rela & ted to medi- & & Constructive Feedback (CF) & & \\
\hline & cal education after you joined MMMC & & & 22. I get constructive feedback from my & 69.6 & 30.4 \\
\hline & & Cumulative & Cumulative & $\begin{array}{l}\text { peers at MMMC for my professional } \\
\text { development }\end{array}$ & & \\
\hline & & $\begin{array}{l}\text { to strongly } \\
\text { agree (\%) }\end{array}$ & $\begin{array}{l}\text { to strongly } \\
\text { disagree }\end{array}$ & $\begin{array}{l}\text { 23. I give feedback to my colleagues at } \\
\text { MMMC }\end{array}$ & 73.8 & 26.1 \\
\hline & & & (\%) & 25. I am improving professionally due to & 60.8 & 39.1 \\
\hline & ve Participation (AP) & & & constructive feedback that I receive at & & \\
\hline & am actively involved in research & 60.8 & 39.1 & MMMC & & \\
\hline & vities after I joined MMMC & & & 26. I know how to provide constructive & 73.9 & 26.1 \\
\hline & spend time beyond working hours for & 82.6 & 17.4 & & & \\
\hline & -directed learning activities leading to & & & Previous Experiences (PE) & & \\
\hline & professional development & & & 27. My experiences at MMMC has & 82.6 & 17.4 \\
\hline & I find time to understand the ongoing & 65.2 & 34.8 & helped me in becoming a lifelong learner & & \\
\hline & earch activities at MMMC & & & 28. My previous academic environment & 47.8 & 52.2 \\
\hline & evant Learning (RL) & & & enhanced my self-directed learning & & \\
\hline & felt the need for continuous self- & 87 & 13 & activities & & \\
\hline & cted learning after joining MMMC & & & 29. My learning experiences at MMMC & 69.6 & 30.4 \\
\hline & $\begin{array}{l}\text { I feel that involving myself in research } \\
\text { vities help me develop professionally }\end{array}$ & 100 & 0 & $\begin{array}{l}\text { have enhanced my self-confidence in } \\
\text { embarking on new projects }\end{array}$ & & \\
\hline
\end{tabular}

\begin{tabular}{|c|c|c|}
\hline $\begin{array}{l}\text { 14. I involve myself in the departmental } \\
\text { activities as I feel it is relevant to my } \\
\text { career development }\end{array}$ & 95.6 & 4.3 \\
\hline 16. At MMMC, there is ample scope for & 91.3 & 8.7 \\
\hline
\end{tabular}

relevant self-learning that fosters professional development

\section{Safe, non-threatening Environment (SE)}

10. I am rewarded for my accomplishments in activities related to my selfdirected learning at MMMC

11. I involve myself in activities related to self-directed learning because of internal motivation

15. I was made aware about the relevance of continuous education by my peers at MMMC

17. After joining $M M M C$, I have no scope for further professional development

18. The environment at MMMC makes me grow professionally and personally

19. I am inhibited in my professional development activities/research because of interference from my peers

\section{$56.5 \quad 43.5$}

$91.3 \quad 8.7$

$96.6 \quad 30.4$

$4.3 \quad 95.7$

$87 \quad 13$

8.7

\section{Table 2. Responses of Force field analysis.}

\begin{tabular}{|c|c|}
\hline Favorable factors & Unfavorable factors \\
\hline $\begin{array}{l}\text { Encouragement and support from } \\
\text { the Dean }\end{array}$ & Heavy teaching load \\
\hline Good leadership of the Dean & $\begin{array}{l}\text { Lack of sufficient research funds } \\
\text { and infrastructure to conduct } \\
\text { experimental research }\end{array}$ \\
\hline $\begin{array}{l}\text { Healthy environment in the } \\
\text { institution }\end{array}$ & Lack of experienced guides \\
\hline Cooperative colleagues & $\begin{array}{l}\text { Resistance to medical education } \\
\text { research by a few faculty }\end{array}$ \\
\hline Flexibility to experiment & $\begin{array}{l}\text { Unwillingness to change the tradi- } \\
\text { tional pattern of teaching }\end{array}$ \\
\hline $\begin{array}{l}\text { Good rewards for academic } \\
\text { achievements } \\
\text { Support from Head of the depart- } \\
\text { ment }\end{array}$ & Personal interference \\
\hline
\end{tabular}




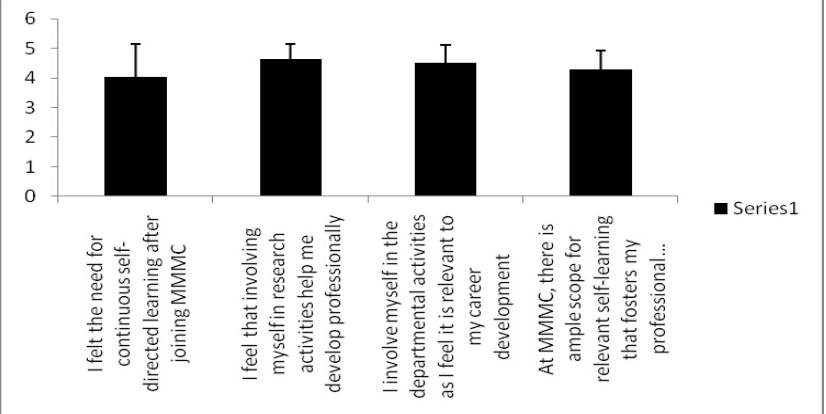

Figure 1. Mean scores for Relevant Learning (RL)

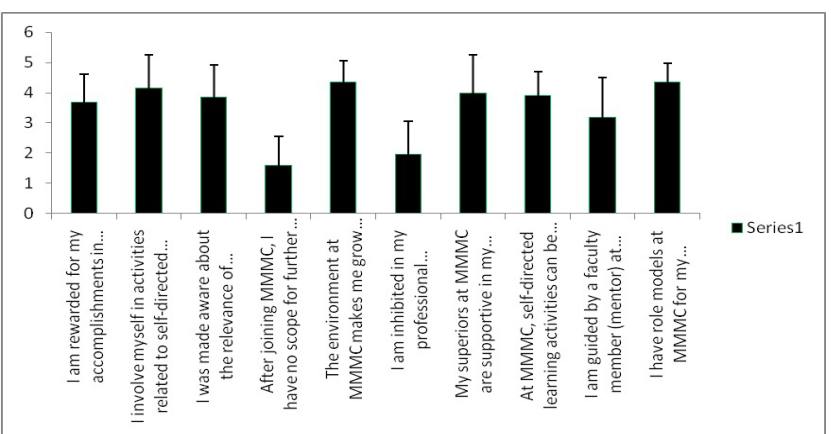

Figure 2. Mean scores for Safe, non-threatening Environment (SE).

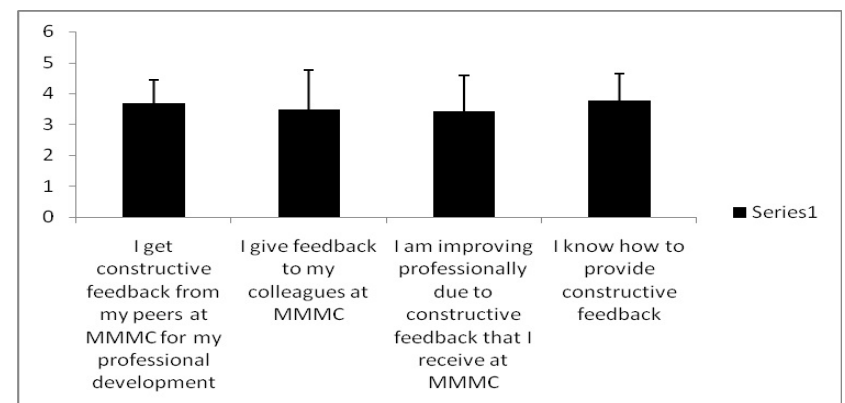

Figure 3. Mean scores for Constructive Feedback (CF).

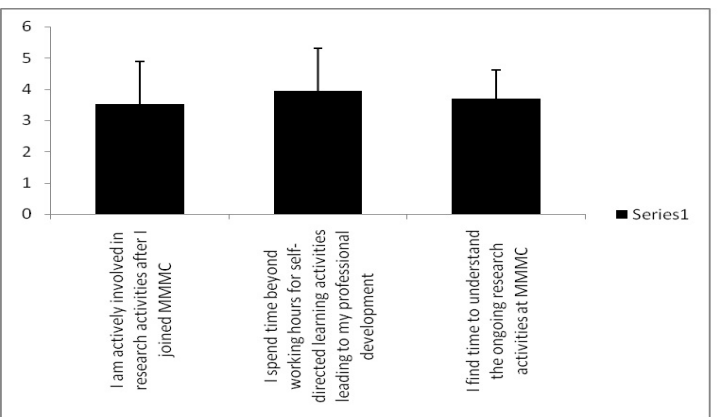

Figure 4. Mean scores for Active Participation (AP).

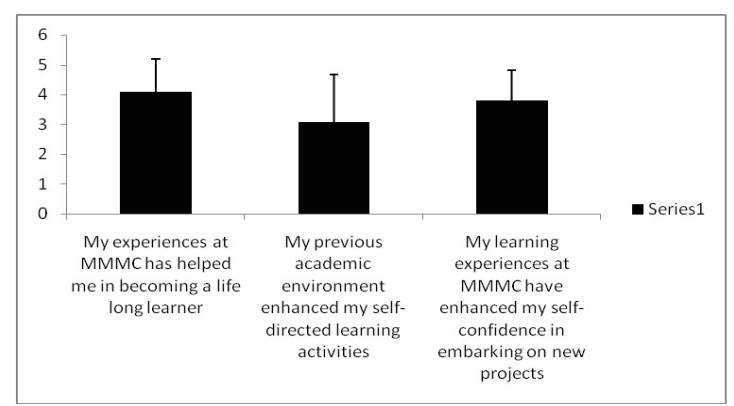

Figure 5. Mean scores for Previous Experiences (PE). environment at MMMC makes me grow professionally and personally) and 30 (I have role models at MMMC for my professional development) were considered the most important attributes among those in 'safe, non-threatening environment'. Among the items under 'constructive feedback', item 22 (I get constructive feedback from my peers at MMMC for my professional development) received the highest rating and item 27 (My experiences at MMMC has helped me in becoming a lifelong learner) was rated as the highest in 'previous experiences'. Frequency analysis of the responses (Table 1 ) revealed that $82.6 \%$ percent of the faculty members at MMMC spend time beyond working hours for self-directed learning activities leading to their professional development. Eighty seven percent responded that they felt the need for continuous self-directed learning after joining MMMC. Ninety six percent felt that they involved in the departmental activities as they feel it was relevant to their career development. Ninety one percent felt that at MMMC, there is ample scope for relevant selflearning that fosters their professional development. Ninety one percent agreed that they involve in activities related to self-directed learning because of internal motivation. Only $4.3 \%$ felt that after joining MMMC, there is no scope for further professional development. Ninety one percent felt that they have role models at MMMC for their professional development. Eighty seven percent agreed that the environment at MMMC makes them grow professionally and personally and $82.6 \%$ felt that their experience at MMMC has helped them in becoming a lifelong learner.

The results of force field analyses are summarized in table 2. The faculty felt that MMMC offers considerable flexibility and opportunities for continuing professional development along with their prevailing role as teachers. They also acknowledged the support and motivation they receive from the top management of the institution as favorable factors. The unfavorable factors included insufficient research funds, lack of experienced research guides and overload.

\section{DISCUSSION}

The overall perception of faculty members revealed that the environment at MMMC was conducive for professional development. The present study helped to understand the refinement processes (if any) to be undertaken at the institution to enhance professional development of faculty members. It was encouraging to see a low rating for items 17 (After joining MMMC, I have no scope for further professional development) and 19 (I am inhibited in my professional development activities/research because of interference from my peers). Nevertheless, better research facilities and provision of more research funds were suggested. Force field analysis specifically highlighted the support and encouragement (in the form of a few practices followed in the institution under the auspices of Manipal Univeristy, India) faculty members 
received from the management in pursuing professional development activities. ${ }^{8}$ In the following sections, authors make an attempt to share a few of these practices which may be helpful for medical schools especially in the developing countries that lack precise proposals for faculty development.

\section{Active participation in self-directed learning activities}

Adults should be challenged to move to increasingly advanced stages of personal development. ${ }^{9}$ According to Rogers, the adult learning process is facilitated when the learner participates completely in the learning process and has control over its nature and direction. ${ }^{10}$ At MMMC, every year, each faculty member is required to respond to the Performance Assessment System (PAS) which functions as a yardstick to measure the faculty members' contribution to teaching, research and other academic activities. Based on the score obtained in the PAS, the faculties are categorized into three categories. This practice serves as a catalyst for the faculty to be involved in professional development activities. Additionally, faculty members are encouraged and supported to pursue a Ph.D degree under eligible guides in the university. It is worth mentioning that Manipal University has made it possible for a faculty to do Ph.D concurrently with his/her appointment. Faculty members are made aware of the need for learning something new by incorporating these academic policies.

These factors serve as sources of external motivation and the faculty takes the initiative to involve themselves in relevant learning, fully aware of the need and importance of self-directed learning. When the faculty members are involved in these, they are engaged in self-directed learning. They take the responsibility of learning on their own. It is reported that an estimated 70 percent of adult learning is self-directed learning. ${ }^{11}$ Melaka Manipal Medical College provides an academically and emotionally safe environment for learning, as perceived by the faculty, enabling them to recognize and value adult learner-centered learning. Additionally, faculty members are encouraged to pursue faculty development fellowship programs like Foundation for Advancement of International Educational Research (FAIMER). ${ }^{12}$

Every week the institution has the Faculty Council meet, where all the faculty members meet and discuss academic matters. All faculty members are required to present a research paper in which he/she has been involved and also a general topic, at least once in the meeting. This is an example of another effective practice that instigates the faculty to pursue professional development activities.

Relevant learning based on the extent to which the need is felt

It is reported that adults are interested in learning which has immediate relevance to their jobs or lives (topics of immediate value). ${ }^{13,14}$ At MMMC, many faculty members pursue part-time Ph.D, mainly because it will help them in their promotion upon successful completion, Adult learners are more problem-centered and want to make learning applicable to their lives. They view learning as most desirable when it is relevant and can be used currently rather than as something to be accessed in the distant future. ${ }^{14}$ After joining MMMC, the staff felt that involving in research activities help them to grow professionally. The institution (under the auspices of Manipal University, India recognize faculty members' involvement in professional development activities which motivates the faculty to engage themselves in such activities. For example, those faculty who earn some 'credit points' by publishing in peer reviewed journals (national/international) have the opportunity to present a paper in an international conference for which the university bears the expenses incurred for travel and registration fee. This motivates many faculty members to actively participate in research, aware of the relevance of doing so.

\section{Safe, non-threatening environment}

Educational environment is one of the most cardinal factors influencing one's learning; be it a child or adult. It is reported that adults generally learn best in an atmosphere that is non-threatening and supportive of experimentation. ${ }^{15}$ WHO has raised the need for providing the best working conditions for faculty as a central component of quality assurance in medical education. ${ }^{16}$ At $\mathrm{MMMC}$, the approach taken for faculty development is congenial; respecting each one's circumstances, ability and interest. Support for adult learners can be provided through a learning environment that meets both their physical and psychological needs. ${ }^{17,18}$ It is reported that developing an atmosphere in which adults feel both safe and challenged should be the goal. .,19,20 $^{2}$ In a study conducted by Pololi et al, the participants perceived that a safe, supportive, self-directive, egalitarian learning environment during a Collaborative Mentoring Program fostered their professional development. ${ }^{21}$ The environment at MMMC nurtures positive self-concept and self-esteem. As revealed by the faculty, it provides opportunities to practice new learning, and allows each one to grow professionally at their own pace.

\section{Constructive feedback}

Sachdeva reports that effective feedback plays a critical role in helping adult learners achieve their educational goals and reach their maximum potential. ${ }^{22}$ As stated by Ammon-Gaberson, as adults engage in new learning, they need feedback about their progress. ${ }^{23}$ At MMMC, faculty who wish to pursue a Ph.D degree needs to present their research proposal in the institutional faculty meet. This is a platform where they are exposed to constructive criticisms which ultimately lead to the refinement of the project. Additionally, faculty members who wish to present papers in international conferences are required to present the paper among the institutional review board, before they proceed for the conference. This is another occasion where the faculty members are expected to come out with their best. 


\section{Learning based on previous experiences}

Adults are equipped with a plenitude of discrete life experiences which serve as a basis for further learning. ${ }^{24-25}$ It is reported that prior learning experiences have the potential to enhance or interfere with new learning. ${ }^{9} \mathrm{~A}$ few faculty at MMMC have previously worked in other institutions prior joining MMMC. After joining MMMC, they feel that the ambience of the institution reflects a positive learning environment which assists them in connecting the current learning experience to something learned in the past.

\section{CONCLUSION}

The present study focused on the scope for professional development at MMMC by describing a few effective practices followed in the institution. The faculty members at Melaka Manipal Medical College (MMMC) felt that, it is an environment

- where faculty feels non-threatened, where individual needs, uniqueness are honored, talents are acknowledged and respected

\section{REFERENCES}

1. Singh T, Bansal P, Sharma M. A need and necessity for faculty development: the role of medical education units in the Indian context. SEAJME 2008; 2:1-6.

2. MacDougal J, Drummond MJ. The development of medical teachers: an enquiry into the learning histories of 10 experienced medical teachers. Med Educ 2005; 39: 1213-1220.

3. Adkoli BV, Sood R. Faculty development and medical education units in India: A survey. NMJI 2009; 22(1): 28-32.

4. Knowles M. The Modern Practice of Adult Education. From pedagogy to andragogy. 2nd ed. Englewood Cliffs, NJ: Cambridge Adult Education Prentice Hall Regents; 1980.

5. Knowles M. The adult learner: a neglected species. 4th ed. Gulf Publishing Company; 1990.

6. Cranton P. Planning instruction for adult learners. Middleton, $\mathrm{OH}$ : Wall and Emerson; 1989.

7. Lewin K. 'Field Theory in Social Science'. New York: Harper and Row; 1951.

8. Ramnarayan K, Rao SG, Rao AK. Academic Incentives-The Manipal Experiment. University News 1995;33: 1-2.

9. Cross KP. Adults as Learners. San Francisco: Jossey-Bass; 1981.

10. Rogers CR. Freedom to learn. Columbus, OH: Merrill; 1969.

11. Smith RM. Learning How to Learn: Applied Theory for Adults. Chicago: Follett; 1982.

12. Burdick WP, Morahan PS, Norcini JJ. Slowing the brain drain: FAIMER education programs. Med Teach 2006; 28 (7): 631-634.

13. Kind T. Learning in practice and maintaining certification in pediatrics. Pediatr Rev 2007 May;28(5):23-9.

14. Crawford DL. The Role of Aging in Adult Learning: Implications for Instructors in Higher Education. New Horizons for Learning (December); 2004. Available from: http://www.newhorizons.org/ lifelong/higher_ed/Crawford.htm.
- that fosters intellectual freedom and encourages experimentation and creativity

- that kindles active participation in professional development activities

- which has feedback mechanisms that tells faculty members what works best for them

Nevertheless, the need for provision of more research facilities and funds were felt and suggested.

The study also threw light upon a few avenues for professional development among teachers in medical schools in India. Institutions play a pivotal role in facilitating professional development of its faculty. ${ }^{26}$ Successful implementation and monitoring professional development satisfaction among faculty members might nurture their nascent interests/qualities/capabilities.

\section{ACKNOWLEDGEMENTS}

The authors wish to express their heartfelt gratitude to all faculty members who participated in the study.

15. Lieb S. Adult learning principles, 1991. Available from: http:// honolulu.hawaii.edu/intranet/committees/FacDevCom/guidebk/ teachtip/adults-2.htm.

16. WHO guidelines for Quality Assurance of Basic Medical Education in Western Pacific Region: Available from: httt://www.wpro.who.int/ publications/pub_9290610204.

17. Imel S. Guidelines for working with adult learners. ERIC Digest No. 154. Columbus, OH: ERIC Clearinghouse on Adult Career and Vocational Education. ED 377313, 1994. Available from: http://www. ericdigests.org/1995-2/working.htm.

18. Imel S. Learning Technologies in Adult Education: Myths and Realities No. 17. ERIC Clearinghouse on Adult, Career, and Vocational Education, 2001. Available from: http://ericacve.org/fulltext.asp.

19. Rogers J. Adults learning. 3rd edn. Philadelphia, PA: Open University Press; 1989.

20. Vella J. Learning to listen. Learning to teach: the power of dialogue in educating adults. San Francisco: Jossey-Bass; 1994.

21. Pololi LH, Knight SM, Dennis K, Frankel RM. Acad Med 2002; 77 (5): 377-384.

22. Sachdeva AK. Use of effective feedback to facilitate adult learning. J Cancer Educ Summer 1996; 11(2): 106-118.

23. Ammon-Gaberson KB. Adult learning principles. Applications for preceptor programs. AORN J 1987Apr; 45(4):961-3.

24. O'Brien G. Principles of adult learning. Melbourne, Australia: Southern Health Organization; 2004. Available from http://www. southernhealth.org.au/cpme/articles/adult_learning.htm.

25. Knox AB. Helping Adults Learn. San Francisco: Jossey-Bass; 1977.

26. Jolly BC. Faculty development for curricular implementation. In: G.R.Norman, CPM Vleuten, DI Newble, editors. International Handbook of Research in Medical Education. Dordrecht, The Netherlands: Kluwer Academic Publishers; 2002: 945-963. 